
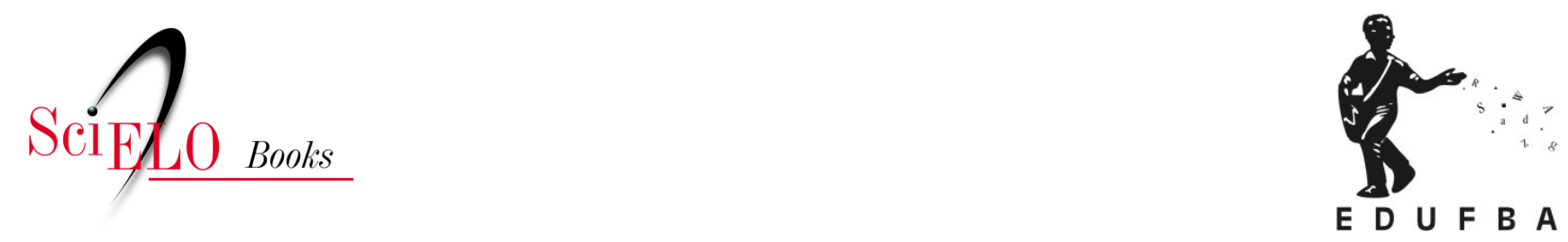

\title{
O movimento afrodescendente por justiça social e as novas leis antidiscriminação
}

\author{
Tanya Katerí Hernández \\ Arivaldo Santos de Souza \\ Luciana Carvalho Fonseca \\ (Tradutores)
}

\section{SciELO Books / SciELO Livros / SciELO Libros}

HERNÁNDEZ, T.K. O movimento afrodescendente por justiça social e as novas leis antidiscriminação. In: Subordinação racial no Brasil e na América Latina: o papel do Estado, o Direito Costumeiro e a Nova Resposta dos Direitos Civis [online]. Translated by Arivaldo Santos de Souza and Luciana Carvalho Fonseca. Salvador: EDUFBA, 2017, pp. 97-136. ISBN: 978-85-232-2015-0. https://doi.org/10.7476/9788523220150.0007. \section{International license.}

All the contents of this work, except where otherwise noted, is licensed under a Creative Commons Attribution 4.0

Todo o conteúdo deste trabalho, exceto quando houver ressalva, é publicado sob a licença Creative Commons Atribição $\underline{4.0}$. 


\section{O movimento afrodescendente por justiça social e as novas leis antidiscriminação}

\section{A legislação antidiscriminação racial na América Latina}

Com a ascensão de governos democraticamente eleitos na década de 1990, os afrodescendentes enfrentaram menos oposição do Estado em relação à sua articulação em Organizações Não Governamentais (ONGs) e organizações comunitárias. Isso, por sua vez, gerou mais espaço para denunciar a má situação de vida e, portanto, muitas ONGs militantes em questões de raça começaram a se proliferar na América Latina. Por exemplo, na Venezuela, ativistas afrodescendentes organizaram o Congresso de Comunidades Afro-Venezuelanas. (REID ANDREWS, 2004, p. 195) Mesmo em Cuba, a despeito das restrições do governo em torno da mobilização política fora do Partido Comunista, uma nova organização negra, a Cofradía de la Negritud, foi formada em Havana, em 1999. Somente no Peru, existem pelo menos 15 organizações ligadas ao movimento social afro-peruano. (GOLASH-BOZA, 2011, p. 5) O "Apêndice A" desta obra oferece uma lista de muitas das organizações de afrodescendentes na América Latina.

Com o ativismo crescente, essas organizações foram capazes de obter importantes apoios políticos e financeiros de fundações estadunidenses e 
europeias comprometidas com a justiça racial, além de apoio de programas de inclusão social do Banco Interamericano de Desenvolvimento, da Fundação Ford e do Grupo Internacional de Direitos Humanos. Ao mesmo tempo, as organizações têm conseguido se comunicar com outras ONGs similares na região através da formação de redes e congressos regionais. Como resultado dessas colaborações internacionais, organizações de afrodescendentes têm conseguido articular suas perspectivas de forma mais potente em seu discurso público. (DIXON, 2008, p. 181-196)

A Conferência das Nações Unidas contra o Racismo, em 2001, e todos os encontros preparatórios que a precederam, foram particularmente importantes para galvanizar um grande número de organizações da sociedade civil para chamar a atenção pública para as mazelas da população afrodescendente na América Latina. Mais de 1.700 ativistas compareceram à conferência preparatória em Santiago do Chile, em 2000. Com a maior participação política das organizações da sociedade civil de afrodescendentes, uma imagem mais realista da situação da hierarquia racial na região começou a ser delineada. Como resultado da organização mais ampla da Diáspora Africana e a consequente atenção da mídia, começou a surgir uma pressão pública sobre os Estados e a atividade legislativa antidiscriminatória começou.

Ainda que seja possível legislar sobre várias formas de combater a discriminação em vários contextos - como no mercado de trabalho, no direito à moradia, nas eleições, em lugares de acesso público (incluindo em situações de consumo, bancos, serviços de educação, atenção à saúde e contratos do governo), entre outros -, a maioria dos países latino-americanos tem tido a tendência de se concentrar em algumas poucas áreas. A tipologia do "Apêndice B" desta obra, "Tipologia das medidas de antidiscriminação racial na América Latina”, exemplifica a variedade de leis antidiscriminação. Para começar, a maioria dos países latino-americanos, tradicionalmente, conta com dispositivos constitucionais genéricos sobre a igualdade, de modo a justificar que a desigualdade racial é abordada da maneira adequada. Um exemplo de dispositivo constitucional genérico com que todos os países latino-americanos contam, com variações, à exceção do Uruguai, é o trecho abaixo extraído da Constituição da Nicarágua: "Todas as pessoas são iguais perante a lei e têm o direito a igual proteção. Não haverá discriminação em razão de origem, nacionalidade, crença política, raça, sexo, língua, opinião, condição econômica ou posição social”. (NICARÁGUA, 1998) 
Além das provisões constitucionais genéricas sobre a igualdade, as medidas antidiscriminatórias abordam aspectos variados, entre os quais: o reconhecimento constitucional, a condição multirracial e multiétnica da população, a atribuição de direitos coletivos de propriedade para negros, como um grupo cultural distinto com laços históricos, para parcelas de terra específicas frequentemente colonizadas por grupos de escravos fugidos, os quilombolas, a imposição de sanções por discriminação racial que negam acesso a lugares públicos, a proibição de discriminação no mercado de trabalho, a obrigatoriedade de inclusão de conteúdo sobre afrodescendentes nos currículos escolares dos países, a proibição de disseminação de ideias baseadas em superioridade racial e a criminalização genérica da discriminação racial. O "Apêndice B" apresenta uma lista, por país, indicando onde essas várias medidas antidiscriminatórias foram adotadas.

\section{0 direito penal como cerne das leis antidiscriminação}

Apesar da ampla gama de medidas contra a discriminação racial, a grande maioria dos países da América Latina usa o direito penal como o meio para lidar com a discriminação racial. A razão desse enfoque está profundamente enraizada na imagem latino-americana de inocência racial. A partir da visão de que os países latino-americanos são racialmente inocentes, uma vez que não há, na América Latina, um histórico de segregação oficial no estilo da legislação Jim Crow americana, a abordagem jurídica dada ao racismo tem sido considerá-lo uma aberração em vez de uma parte sistêmica da cultura nacional. Como resultado, a resposta legal tem sido tratar o racismo como obra de indivíduos isolados, que supostamente possuem preconceitos anormais. Em suma, os racistas são criminosos e não representantes de normas culturais racistas arraigadas. Isso também ajuda a explicar por que a grande maioria das leis contra o discurso de ódio na América Latina faz parte dos códigos penais da região. Infelizmente, limitar a ideia a palavras preconceituosas proferidas pelas pessoas rotuladas como racistas despreza os aspectos estruturais e institucionais da discriminação, que se mantêm em operação mesmo na ausência de comentários racistas. Sobre a situação dos afro-equatorianos, o acadêmico Carlos de la Torre afirma que "Reduzir o racismo a palavras hostis e ações de indivíduos ignorantes, etnocêntricos e provincianos foi uma visão que dominou a sociologia americana até recentemente, mas tal postura não leva em consideração relações de poder”. (DE LA TORRE, 2005) 
Além do mais, alguns países da América Latina mantêm uma abordagem penal singular contra a discriminação. Por exemplo, na República Dominicana, a Lei Contra a Violência Intrafamiliar, de 1997, criminalizou o tratamento desigual e humilhante baseado em raça ou etnia. As pessoas condenadas pelo crime de discriminação podem ser presas por um ano e um mês e multadas em dois ou três salários mínimos. (REPÚBLICA DOMINICANA, 1997, par. III, art. 9) Na Nicarágua, o Código Criminal apena a obstrução de um direito constitucional por motivo de raça ou etnia. (NICARÁGUA, 2007, art. 427, 428) A pena é de seis meses a um ano de prisão. Se a obstrução racialmente motivada de um direito constitucional tiver sido feita publicamente, uma multa adicional pode ser imposta. O Código Criminal nicaraguense também autoriza o aumento da pena para outros crimes quando racialmente motivados. (NICARÁGUA, 2007, art. 36.5)

Ainda que a criminalização da discriminação racial sugira um forte compromisso normativo com a erradicação da discriminação, na prática, ironicamente, pode ter o efeito de tornar o sistema jurídico menos capaz de lidar com os problemas da desigualdade e discriminação. Casos criminais requerem um conjunto probatório mais robusto e um maior ônus da prova que casos civis. Por exemplo, uma análise das queixas peruanas no que diz respeito à experiência de apresentar uma demanda penal por discriminação racial demonstrou que o ônus da prova para casos de discriminação era alto e que, na maioria das vezes, era difícil para a vítima provar que sofreu discriminação. (PERU, 2007, p. 119) Um caso exemplar descrito no estudo é de uma pessoa que apresentou uma denúncia contra o departamento de polícia alegando ter recebido uma multa de trânsito injustamente por causa de sua raça. O promotor de justiça alegou que sua acusação não merecia uma investigação criminal ou persecução penal porque as provas apresentadas não eram suficientes: o querelante havia apresentado uma declaração juramentada sua e de um membro de sua família que havia testemunhado o incidente. É difícil imaginar o que mais o querelante poderia ter apresentado para fundamentar suas alegações. A demanda por mais elementos é assim emblemática da resistência latino-americana em aceitar a discriminação racial como objeto de uma ação penal viável.

Além da relutância de promotores em dar seguimento aos casos de discriminação racial, os magistrados também são relutantes em impor sanções penais. Os sistemas de justiça criminal latino-americanos são sobrecarregados com casos de crimes tradicionais contra a propriedade e crimes de violência 
contra a pessoa. Em um sistema marcado pelo grande volume desses crimes e pelas ineficiências sistêmicas, os crimes de racismo e discriminação racial têm e provavelmente continuarão a ter prioridade baixa.

Ademais, ao confiar a aplicação do direito penal a autoridades públicas, corre-se o risco de a lei ser menosprezada pela inação complacente dos agentes públicos que compartilham o mesmo preconceito racial que os autores da discriminação. De fato, analistas notam que agentes policiais latino-americanos são frequentemente autores de violência racial contra pessoas de ascendência africana, porque encaram sua função como a de proteger a sociedade de "maus elementos" por qualquer meio necessário, sem maior consideração ao Estado de Direito. (PINHEIRO, 1999, p. 1-16) Isso é particularmente perigoso na América Latina, onde é possível observar agentes policiais reiteradamente desencorajando afrodescendentes a registrar ocorrência de discriminação racial; ademais, os mesmos policiais são, frequentemente, autores de discriminação e violência. (BRINKS, 1999, p. 1001-1020)

O contraste entre os contextos cível e criminal é mais bem exemplificado pelo caso Tiririca, no qual o mesmo padrão de discurso de ódio produziu bons resultados na esfera cível, mas não na esfera penal. Francisco Everardo Oliveira Silva, cujo nome artístico é Tiririca, é um humorista brasileiro que lançou uma música, pela Sony Music, intitulada “Veja os cabelos dela”, em 1996. A música, essencialmente, é tirada contra o suposto cheiro ruim, animalesco, das mulheres negras e a feiura do cabelo naturalmente crespo. A letra dizia:

Quando ela passa, me chama atenção / Mas os seus cabelos, não têm jeito não / A sua catinga quase me desmaiou / Olha eu não aguento, é grande o seu fedor / Veja veja veja veja veja os cabelos dela / Veja veja veja veja veja os cabelos dela / Veja veja veja veja veja os cabelos dela / Veja veja veja veja veja os cabelos dela / Parece bom-bril, de ariá panela / Parece bom-bril, de ariá panela / Eu já mandei, ela se lavar / Mas ela teimou, e não quis me escutar / Essa nega fede, fede de lascar / Bicha fedorenta, fede mais que gambá. (CALDWELL, 2004, p. 18)

A ONG feminista negra Criola, juntamente com a ONG Centro de Articulação de Populações Marginalizadas (CEAP) e algumas outras organizações de defesa da justiça social, ajuizaram ações cível e penal contra o cantor e a gravadora. Na esfera penal, os autores moveram uma ação por racismo e perderam porque o juiz afirmou que não havia intenção de ofender as 
mulheres negras. (CUNHA, 1998) Na esfera penal, provar que houve discriminação não foi possível devido ao reduzido número de vezes que indivíduos declaram abertamente sua intenção de discriminar. Como resultado, a música continua em circulação.

Por outro lado, a ação civil foi bem-sucedida. A ação civil pública foi ajuizada sob a égide do artigo $3^{\circ}$ da Constituição, que declara ser objetivo nacional "promover o bem estar de todos sem preconceito de origem, raça, sexo, cor, idade e qualquer outra forma de discriminação”. (BRASIL, 1988, art. 3, par. IV $)^{1}$ A ação buscava proteger o direito coletivo de as mulheres negras serem livres de discriminação. Os direitos difusos são uma categoria de direitos que garante a um grupo de indivíduos com interesse comum, ainda que dispersos na comunidade política. (BRASIL, 1985, 1994, 2001) Longe do contexto penal, o qual requer a intenção de discriminar como suporte da ação, a vara cível alegou que a autoria da letra da canção por parte do réu era, por si só, discriminatória, porque as palavras utilizadas provocavam sentimentos de humilhação nas mulheres negras. (RIO DE JANEIRO, 2005) O juízo também levou em consideração que Tiririca era um humorista popular entre as crianças (que era frequentemente televisionado em rede nacional com roupas de palhaço) e que os comentários pejorativos da música são prejudiciais para a formação da juventude negra.

Como compensação pelos danos morais coletivos causados à dignidade, em 2008, o judiciário determinou o pagamento de 300 mil reais mais honorários advocatícios e custas processuais. (BANK OF CANADA, [200-]) Em 2012, o tribunal reformou a decisão para incluir valores retroativos à data do ajuizamento da ação, em 1997, aumentando assim o valor da condenação para 1,2 milhão de reais. Em sistemas romano-germânicos como o brasileiro, os danos morais são destinados a compensar os transtornos emocionais derivados do prejuízo à honra e à reputação de alguém. (LITVINOFF, 2004, p. 183, 208-211) Frequentemente, não se reconhecem danos morais para todos os tipos de ação de responsabilidade civil, mas somente àqueles que ofendem a dignidade. O pagamento em dinheiro pelo dano coletivo ao direito das mulheres negras foi pago ao Fundo de Defesa dos Direitos Difusos, administrado pelo Ministério da Justiça, para a criação de programas educacionais 
antirracistas para a juventude, a serem veiculados no rádio, televisão, filmes e material impresso para crianças do ensino fundamental no país.

O caso Tiririca mostra que, no contexto cível, a ausência de penas de prisão permite ao juiz considerar perspectivas modernas sobre igualdade racial ao decidir se a discriminação que tem sido historicamente prevalente na América Latina, mas invisível enquanto "cultura”, pode ser judicializável. A abordagem cível pode proporcionar teorias de discriminação mais gerais e critérios probatórios menos rigorosos. (RACUSEN, 2002, p. 87-88) Além disso, na área cível, há um menor risco de aplicação seletiva da lei, aplicação essa que atinge as populações vulneráveis desproporcionalmente. Isso porque, ao contrário da persecução criminal, o Estado não é o titular da ação. Todavia, em razão da noção dominante de que a lei penal contra a discriminação racial reflete a suposta seriedade com a qual o Estado encara o racismo, o desenvolvimento de medidas cíveis tem deixado a desejar e seu alcance tem sido limitado.

\section{O exemplo peruano do direito do trabalho e do consumidor}

No Peru, além do direito penal contra a discriminação (PERU, 2000), há várias leis não penais que proíbem a discriminação racial. A primeira lei, promulgada em 1997, proibia requisitos discriminatórios em ofertas de emprego e de acesso à educação. (PERU, 1997) Depois disso, a imprensa começou a tornar públicas as práticas discriminatórias nos clubes de dança de Lima, que reiteradamente negavam a entrada de afro-peruanos. (INTERNATIONAL DEVELOPMENT RESEARCH CENTRE, [200-]) O Instituto para a Livre Concorrência e Propriedade Intelectual (Indecopi), um organismo governamental para garantir a concorrência econômica aberta e justa e proteger os direitos de propriedade intelectual dos cidadãos (PERU, 1992), investigou e depois lançou uma campanha de pressão política contra as casas noturnas, em favor dos consumidores. (INTERNATIONAL DEVELOPMENT RESEARCH CENTRE, [200-]) Gravações de vídeo foram usadas no caso para provar que a discriminação racial foi a única razão pela qual alguns consumidores tiveram sua entrada negada. Em resposta ao clamor público decorrente dos incidentes, o Congresso aprovou uma segunda lei, a Lei $\mathrm{n}^{0} 27.049$, proibindo qualquer forma de discriminação racial pelos proprietários de estabelecimentos abertos ao público. Enquanto a lei é clara ao afirmar que a discriminação em estabelecimentos comerciais é proibida, o Congresso rejeitou a criação de uma ação processual diferenciada para as 
pessoas discriminadas. Em vez disso, os dispositivos da Lei no 27.270 são regulamentados pelo Decreto Supremo n ${ }^{\circ}$ 002-98-TR, o qual autoriza a Autoridade Administrativa Laboral a investigar atos discriminatórios, mas apenas após a apresentação de um pedido de investigação. (INTER-AMERICAN COMMISSION ON HUMAN RIGHTS, 2000)

Enquanto consumidores individuais podem reclamar junto ao Indecopi ou ao Serviço de Atendimento ao Cidadão (SAC), o processo, em si mesmo, apresenta problemas. Primeiro, o Indecopi cobra uma taxa por cada reclamação apresentada. (DENUNCIAS, [200-]) A taxa é um problema para os membros da comunidade afro-peruana, em grande maioria pobres. Segundo, a maioria dos cidadãos não sabe como dar seguimento ao processo, e há muitas reclamações por tratamento rude e péssimos serviços prestados pelos agentes oficiais. (VEGA, 2006) Terceiro, o Indecopi não tem escritórios espalhados pelo país, tornando a tarefa de iniciar o processo, e acompanhá-lo, difícil.

Para um processo ser bem-sucedido na área do direito do consumidor, o autor tem o ônus de provar o tratamento diferenciado recebido, ao passo que o proprietário deve mostrar que suas ações foram objetivas e justificadas. Caso reste provada a idoneidade do proprietário, o consumidor deve arcar com o ônus de provar que a justificativa do proprietário é um pretexto para discriminá-lo racialmente. Esse processo se assemelha ao modelo estadunidense de provar a discriminação, conforme o título VII da Lei de Direitos Civis de 1964. Portanto, torna-se muito difícil provar à agência de proteção ao consumidor que a pessoa foi discriminada na condição de consumidor. Ainda que essa seja uma reclamação popular, alguns têm apontado que há exigências aplicadas arbitrariamente pelos oficiais da agência de proteção ao consumidor que impedem pessoas de apresentarem uma reclamação. Uma dessas exigências é mostrar um comprovante do lugar em que a pessoa sofreu discriminação. Esse requisito é particularmente surpreendente, uma vez que o ponto crucial da reclamação é que a pessoa teve sua entrada ao estabelecimento negada e, portanto, não poderia consumir algo que pudesse usar para obter um comprovante fiscal. Outro problema na aplicação das leis de proteção ao consumidor é concentrar-se no acesso do consumidor a locais de entretenimento, em vez de enfocar o tratamento não discriminatório em unidades de atendimento à saúde. Essa é uma omissão significativa, uma vez que os serviços de atenção à saúde foram considerados a esfera em que a discriminação racial é mais predominante, segundo um estudo sobre o racismo no Peru. (PLANAS; VALDIVIA, 2009, p. 35) 
Há também uma tendência crescente entre os proprietários de certos estabelecimentos que, para burlar as leis antidiscriminação, alegam que operam negócios que atendem exclusivamente turistas norte-americanos e europeus, os quais supostamente preferem contratar um setor de serviços que empregue apenas brancos. (VEGA, 2006) Particularmente em grandes cidades como Lima, empresários que usam a estratégia do "somente turistas" têm sido bem-sucedidos não apenas em excluir afro-peruanos, mas também em evitar terem suas práticas discriminatórias detectadas. (APRODEH, 2005)

O contexto das relações de trabalho apresenta desafios de aplicação similares. O Ministro do Trabalho e Promoção do Emprego (MTPE) é o encarregado de investigar alegações de discriminação. (ESTADOS UNIDOS, 2007) Para começar esse processo, é necessário levar uma reclamação ao conhecimento do MTPE; se for constatado que a parte acusada publicou um anúncio discriminatório, então ela será multada. Essa lei também obriga os veículos da mídia a levar ao conhecimento das autoridades peruanas tais anúncios discriminatórios e a colaborar na investigação dos casos. Um empreendimento que violar a lei pode ser fechado por um período inferior a um ano. Uma vítima de discriminação também pode acionar judicialmente um empregador pela violação da Lei $\mathrm{n}^{\mathrm{o}}$ 26.772, por meio de uma vara trabalhista ou através do Tribunal Constitucional, para casos envolvendo direitos previstos na Constituição. (ESTADOS UNIDOS, 2007)

Em casos de oferta de emprego, as regras do MTPE permitem aos empregadores fazer algumas exigências que poderiam ser consideradas discriminatórias se eles puderem demostrar uma "justificativa razoável e objetiva", ou seja, se as exigências estiverem relacionadas à qualificação necessária para o emprego. (VEGA, 2009) Então, por exemplo, uma exigência racial poderia ser supostamente admitida para a contratação de um ator para interpretar um papel racialmente específico, do mesmo modo que, nos Estados Unidos, o título VII prevê uma exceção à proibição de usar a origem nacional como requisito para contratação (mas proíbe exigências com base em raça para relações de emprego). (RUTHERGLEN, 2010, p. 129)

Essa lei, entretanto, não trata adequadamente o problema dos anúncios discriminatórios, e ainda é comum encontrar empregadores lançando mão da expressão "boa aparência" (buena aparencia) como requisito, um eufemismo bastante conhecido para descrever uma pessoa com fenótipo branco. Todavia, o MTPE informou que entre 1998 e 2006 apenas 14 reclamações foram feitas, e 
seis das reclamações foram resolvidas. (PERU, 2007, p. 205) Em 2010, o MTPE recebeu 28 reclamações e multou três empresas infratoras. Depois disso, o Ministério do Trabalho reeditou o esforço para combater esse tipo de anúncio de emprego discriminatório e prometeu reforçar o cumprimento. (PROGRAMA NACIONAL DE EMPLEO JUVENIL, 2010) Concretamente, o MTPE anunciou que implementaria um sistema integral para administrar as reclamações dos candidatos a emprego que acreditam terem sofrido discriminação. Esse novo sistema permitiria indivíduos a apresentar reclamações por escrito, por telefone ou pela internet.

A discriminação no mercado de trabalho, durante a relação de emprego, é proibida tanto pela Constituição peruana como pela Lei de Produtividade no Trabalho. (PERU, 1997) Segundo essa lei, um juiz pode determinar medidas que impeçam a discriminação e multar o empregador. Se o empregado quiser rescindir o contrato de trabalho por causa de práticas discriminatórias, o empregado pode ser indenizado. Essa lei também invalida a extinção do contrato por motivo discriminatório. Conforme essa lei, se o juízo determinar que a reclamação tem fundamento, o trabalhador pode ser reintegrado ao trabalho ou optar pela indenização.

Todavia, é provável que a capacidade de as leis trabalhistas reformadas lidarem de forma eficaz com a discriminação racial seja dificultada pela contínua ambivalência do governo nas situações em que é preciso lidar diretamente com as necessidades da população afro-peruana. Por exemplo, o governo se desculpou oficialmente, em 2009, na forma de uma resolução estatal, expressando "arrependimento histórico à população afro-peruana pelos abusos, exclusão e discriminação cometidos contra os mesmos no período colonial e no presente”. (PERU, 2009) Contudo, durante a cerimônia oficial em que o presidente anunciou o pedido de desculpas em nome do Estado, ele afirmou que as desculpas seriam capazes de "limpar o Estado e a História de tal culpa". (ALAN GARCÍA, 2009) Ficou a impressão de que o presidente García considera que os danos contra seus afrodescendentes são suficientemente pequenos para serem solucionados com um simples pedido público de desculpas. Desse modo, temos mais um exemplo de como a comparação implícita da questão racial na América Latina com o "racismo verdadeiro" dos Estados Unidos ainda situa o Peru como um inocente racial, um herdeiro passivo do racismo colonial espanhol e um país em que a falta de uma segregação no estilo Jim Crow isentaria o Estado de tomar qualquer ação direta para remediar a discriminação. Portanto, 
será difícil promover reformas legais mais efetivas contra a discriminação, com um governo confiante de que um pedido de desculpas formal é o bastante para corrigir os danos causados. Ao mesmo tempo, dada a luta afro-peruana contra a invisibilidade no seu próprio país, o reconhecimento da existência de afro- peruanos e da discriminação contra o grupo, feito por ocasião do pedido de desculpas, pode ajudar a impulsionar os esforços da comunidade afro-peruana em defesa dos direitos civis.

\section{O exemplo colombiano de constituições multiculturais, o direito à terra e a reforma curricular}

A Constituição Colombiana de 1991 reconhece e protege a diversidade cultural e étnica da nação. (COLÔMBIA, 1995, art. 7) Dessa maneira, a Colômbia se juntou a vários outros países latino-americanos, como Bolívia, Equador, Guatemala, México, Nicarágua, Paraguai e Venezuela, no reconhecimento constitucional do caráter multicultural e multiétnico da nação. Existem diversas definições sobre em que consiste uma constituição "multicultural”. Os cientistas políticos discutem o conceito de multicultural como uma cidadania diferenciada, ao passo que os juristas geralmente divergem e consideram o conceito como o constitucionalismo de um Estado multicultural. (CARLSON, 2002, p. 1470-1487) Neste trabalho, eu caracterizo uma constituição multicultural como aquela em que o texto explicitamente se refere à importância da proteção por parte do Estado à diversidade étnica e cultural da nação ou aquela que reconhece a nação como multiétnica e busca facilitar políticas de inclusão. (MALDONADO, 2006)

Contudo, nem todas as constituições multiculturais situam as comunidades afrodescendentes da mesma forma. Juliet Hooker chama atenção ao fato de que os Estados latino-americanos têm primeiramente concebido os direitos multiculturais como pertencentes a povos indígenas, que são vistos como merecedores da condição de membros de grupos "étnicos", por outro lado, os afrodescendentes têm sido frequentemente excluídos da condição de sujeitos "raciais" distintos, fazendo com que sua identidade étnica não mereça proteção constitucional. (HOOKER, 2009, p. 80-82) A dicotomia feita entre povos indígenas dignos de reconhecimento "étnico" e afrodescendentes não dignos de reconhecimento "racial” ignora a racialização dos povos indígenas, assim como as identidades culturais das comunidades afrodescendentes. Por essa razão, a 
Colômbia se destaca por ter sido um país que incluiu os afrodescendentes, ao mesmo tempo que exemplifica as limitações de uma nação em equiparar direitos multiculturais com a condição de grupo étnico. Desse modo, a Colômbia contrasta exemplarmente com países como México e Venezuela, que excluíram completamente os afrodescendentes de seu panorama de direitos multiculturais. A Colômbia também contrasta com aqueles países que reconheceram aos afrodescendentes os mesmos direitos coletivos à terra e à cultura, tais como Guatemala, Honduras e Nicarágua. Juliet Hooker caracteriza a Colômbia, o Brasil, o Equador e o Peru como países onde afrodescendentes obtiveram alguns direitos constitucionais multiculturais, mas não na mesma extensão que os obtidos pelas comunidades indígenas.

A Constituição colombiana declara que "reconhece e protege a diversidade cultural e étnica da nação colombiana”. (COLÔMBIA, 1995, art. 7) O artigo transitório 55 da Constituição de 1991 determina que leis que reconheçam o direito dos afrodescendentes à propriedade coletiva da terra sejam aprovadas. Assim, as provisões constitucionais foram intensificadas por legislação infraconstitucional. Como forma de implementar o mandamento constitucional do artigo 55, foi aprovada em 1993 a Lei ${ }^{\circ}$ 70, para proteger os direitos de afro-colombianos à propriedade da terra. A lei prevê a eleição de líderes que representem as comunidades em questões relativas à terra e a outros assuntos mediante um sistema de consulta prévia. $\mathrm{O}$ artigo $7^{\circ}$ da Lei $\mathrm{n}^{\circ} 70$ dispõe que os títulos coletivos de terra são inalienáveis, não passíveis de execução e imprescritíveis. Entretanto, essa lei se limita à área da Costa do Pacífico e outras zonas especificamente delimitadas. (THE BERNARD AND AUDRE CENTER FOR HUMAN RIGHTS AND JUSTICE, 2007, p. 8) Outras áreas explicitamente não incluídas nas provisões legais são áreas urbanas, territórios indígenas, áreas de parques nacionais e áreas reservadas para segurança e defesa nacional. O que isso efetivamente significa é que um grande número de afrodescendentes urbanos, fora da Costa do Pacífico, estão excluídos da proteção constitucional porque eles não são considerados vinculados às parcelas específicas de terra, diferentemente das comunidades indígenas com seus títulos coletivos de terra. A Lei $\mathrm{n}^{\circ} 70$, então, apenas lida com as necessidades de um segmento da população afro-colombiana.

E mesmo os afro-colombianos que podem pleitear a titularidade da terra nos moldes da Lei $\mathrm{n}^{\circ} 70$ têm obtido apenas resultados modestos. Isso porque as ações são prolongadas, pois dependem de estudos técnicos sobre as terras. 
Além disso, a Lei 70 requer que apenas terras consideradas devolutas (terras baldías) possam ser apropriadas como propriedade coletiva. Considerando que os afro-colombianos são regionalmente e etnicamente diversos, os povos não vivem na mesma terra (de fato, alguns afro-colombianos não usam sequer o espanhol como língua nativa. Os raizales são um grupo étnico que fala uma espécie de língua crioula que mistura inglês afro-caribenho). Além disso, o processo de titulação da terra é especialmente exigente porque requer a produção de estudos históricos, demográficos, econômicos e cartográficos da comunidade que reivindica a propriedade coletiva da terra.

Do mesmo modo, muitos afro-colombianos têm sido dissuadidos de iniciar o processo de titulação das terras pela violência de grupos paramilitares e pelo exército colombiano. (AROCHA, 1998, p. 70-89) Os organizadores de comunidades afro-colombianas que buscam a propriedade coletiva têm sido considerados guerrilheiros e terroristas e, portanto, têm sido alvo de violência pelo governo interessado em controlar as áreas afro-colombianas ricas em recursos naturais em favor do desenvolvimento empresarial. (ASHER, 2009) Adicionalmente, grupos paramilitares de direita, há muito envolvidos com tráfico de drogas, também estão envolvidos em ações para se apossar da terra. (ROSERO, 2002, p. 547-559) Com isso, há pelo menos um estudo com informação de que $33 \%$ dos afro-colombianos foram expulsos de suas próprias terras por grupos armados. (GLOBAL RIGHTS PARTNERS FOR JUSTICE, [200-]) Dentre as pessoas expulsas de suas terras por causa da guerra civil, o mais alto percentual é o de afro-colombianos. (CONSULTORÍA PARA LOS DERECHOS HUMANOS Y EL DESPLAZAMIENTO, 2008; CONSULTORÍA PARA LOS DERECHOS HUMANOS Y EL DESPLAZAMIENTO, [200-]) Ademais, um afro-colombiano tem $84 \%$ mais chances de perder suas terras do que um mestiço. Apenas em 2007, dentre a população colombiana com registro de propriedade coletiva de terras, $79 \%$ foram expulsos de suas terras. (GARAVITO; SIERRA; ADARVE, 2008, p. 34-35) A expulsão dos afro-colombianos (e o de comunidades indígenas também) de suas terras é tão significativa que, em 1999, as Nações Unidas oficialmente advertiram o governo colombiano para lidar com essa forma de discriminação racial. (UNITED NATIONS HIGH COMMISSION FOR HUMAN RIGHTS, 1999) Depois disso, a Corte Constitucional da Colômbia avaliou a política de governo para tratar da situação dos desabrigados e estabeleceu que a política era inadequada e inconstitucional por violar direitos fundamentais de cidadãos colombianos. (COLÔMBIA, 2004) Desde então, 
conforme ordem da corte, o governo tem sido obrigado a criar políticas para prevenir a remoção forçada de proprietários de terras, além de mitigar as más condições de vida dos expulsos das suas terras. Infelizmente, as deliberações do governo, no que diz respeito às necessidades dos expulsos, não têm enfocado no impacto particular sobre os afro-colombianos como um grupo. (MARTÍNEZ, 2006, p. 42-47) $)^{2}$

Por outro lado, o governo tem se mostrado disposto a considerar os afro-colombianos como um grupo, no que diz respeito à reforma educacional. Em 1998, o presidente Álvaro Uribe aprovou um decreto presidencial ordenando que as escolas ensinem história e cultura afro-colombianas. (COLÔMBIA, 1998) O artigo 160 da Lei 115 dispõe que a diretoria educacional de cada distrito deve incluir um membro representando a comunidade afro-colombiana local, se tal comunidade local existir. (COLÔMBIA, 1994, art. 160, \$10) Espera-se que com a maior exposição educacional às contribuições dos afro-colombianos à sociedade colombiana, uma verdadeira igualdade racial se tornará desejável para toda a população.

Contudo, a promessa das constituições multiculturais precisará confrontar a longa e arraigada história de políticas racialmente excludentes na América Latina. Por exemplo, ao implementar a legislação de "proteção multicultural”, como requer a Constituição, as autoridades governamentais devem consultar as comunidades afrodescendentes antes de tomar decisões que afetem as terras das comunidades. Os afro-colombianos enfrentam barreiras para o processo de consulta porque o governo deve, primeiro, oficialmente, reconhecer um "conselho comunitário" de afrodescendentes preestabelecido, antes de os afrodescendentes terem o direito de serem consultados. O processo de reconhecimento oficial tem sido visto como excessivamente burocrático e limitante. Todavia, depois de tantos anos de marginalização, mesmo o reconhecimento constitucional simbólico da importância dos afrodescendentes constitui por si só um sinal de progresso. (VAN COTT, 2000) Uma alternativa às constituições multiculturais tem sido a tentativa brasileira de aprovar leis contra a discriminação com uma abordagem integral.

2 Ao fazer uma busca na internet sobre esse artigo, porque me parecia que na versão consultada faltavam algumas palavras, descobri que seu autor é Luis Gerardo Martínez Miranda e o artigo se intitula "Desde adentro: una aproximación al tema de Verdad, Justicia y Reparación a partir de las víctimas afrocolombianas". 


\section{O exemplo brasileiro de luta por um sistema jurídico antidiscriminatório integral}

Devido aos grandes avanços feitos pelo Brasil no que diz respeito à criação e à aplicação de leis antidiscriminatórias, seu contexto se torna merecedor de atenção especial. A concentração de esforços para usar o direito como veículo de mudança social é particularmente significativa devido à histórica exigência de ser alfabetizado para poder votar. (MARX, 1998, p. 258) Por causa dessa exigência, que perdurou até 1985 e que efetivamente excluía a maioria da população afro-brasileira, a arena política não foi o espaço mais promissor para a mudança social. Assim, a moderna legislação brasileira de direitos civis só começou em 1951, com a aprovação da Lei Afonso Arinos. (BRASIL, 1951) A lei criminalizou a discriminação racial no mercado de trabalho, no comércio, em espaços públicos, no governo e na educação. A discriminação nessas áreas foi declarada crime punido com prisão e multa.

A lei introduziu o que se tornou um padrão na legislação de direitos civis brasileira: tratar a discriminação racial como ofensa penal. Como resultado, a legislação antidiscriminação, historicamente, tem sido subaplicada e, portanto, ineficaz. De fato, a Lei Afonso Arinos é largamente aceita como um mero gesto de relações públicas voltado a mitigar a má impressão deixada quando uma dançarina estadunidense, Katherine Dunham, foi barrada em um renomado hotel brasileiro e, portanto, teria sido a lei decorrente da influência do poder industrial e comercial estadunidense (e não por causa do racismo brasileiro). (TELLES, 2004, p. 38) Consequentemente, a Lei Afonso Arinos não reconheceu o racismo no Brasil, nem procurou remediá-lo, a despeito do fato de ativistas afro-brasileiros em defesa da justiça social terem chamado a atenção do público e da imprensa para o incidente com Katherine Dunham. A lei aprovada era uma versão mais amena de um projeto de lei antidiscriminatória que ativistas afro-brasileiros apresentaram para aprovação. (NASCIMENTO, 2007, p. 148-149)

Apenas nove réus foram condenados nos primeiros 46 anos que se seguiram à aprovação da lei em 1951. (CESAR, 2003, p. 212-213) Durante a ditadura militar brasileira (1964-1986), leis antidiscriminação continuaram a não ser aplicadas e não foram levadas seriamente pelos atores governamentais. Consequentemente, os esforços atuais para usar a arena legal como veículo de transformação social no país ocorrem tendo como pano de fundo algumas leis de direitos civis anteriores, consideradas ineficazes. 
Cada uma das constituições brasileiras resguardou o princípio da igualdade formal perante a lei. Com o retorno à democracia, a atual Constituição de 1988 incluiu várias cláusulas relacionadas à discriminação racial, as quais ativistas sociais conseguiram incluir como parte de uma ampla reforma pós-ditadura militar em 1986. (BRASIL, 1988, art. 5, sec. XLII) No título I, "Dos Princípios Fundamentais", a Constituição estabelece que uma das bases do Estado Democrático de Direito é "promover o bem de todos, sem preconceitos de origem, raça, sexo, cor, idade e quaisquer outras formas de discriminação" (art. $3^{\circ}$, IV). O mesmo título estabelece que o Brasil é regido, nas suas relações internacionais, pelo princípio de repúdio ao terrorismo e ao racismo (art. $4^{\circ}$, VIII).

Por sua vez, o título II da Constituição Federal, que se refere aos direitos e às garantias fundamentais, estabelece no artigo $5^{\circ}$, caput, a igualdade de todos perante a lei e, no artigo 42, que "a prática do racismo constitui crime inafiançável e imprescritível, sujeito à pena de reclusão, nos termos da lei”.

Ademais, o artigo 215, em seu parágrafo $1^{\circ}$, estabelece que "O Estado protegerá as manifestações das culturas popular, indígena e afro-brasileiras, e das de outros grupos participantes do processo civilizatório nacional”. O artigo 216, parágrafo $5^{\circ}$, dispõe que "Ficam tombados todos os documentos e os sítios detentores de reminiscências históricas dos antigos quilombos". Por fim, o artigo 68 do Ato das Disposições Constitucionais Transitórias reconhece aos remanescentes das comunidades dos quilombos, que estejam ocupando suas terras, a propriedade definitiva, devendo o Estado lhes conferir os títulos respectivos. Contudo, em maio de 2008, apenas 87 dos 3.550 quilombos atualmente reconhecidos pelo governo brasileiro receberam seus títulos de terra. (BETWEEN, 2008)

Logo, após a promulgação da Constituição de 1988, leis de direitos civis foram aprovadas. Um ano após a promulgação da Constituição, o Congresso aprovou a Lei ${ }^{0}$ 7.716, que criminaliza a discriminação baseada em raça ou cor em lugares públicos, no mercado de trabalho e no setor privado. (BRASIL, 1989) A lei, conhecida como Lei Caó, era extensa, e muitas críticas foram feitas no sentido de que as disposições eram vagas e continham muitas brechas. (SILVA; SFOGGIA, 1997, p. 11-28) Em seu texto original, a lei criminalizou uma série de ações que são resultantes do preconceito de raça ou cor, incluindo impedir ou obstar o acesso de alguém, devidamente habilitado, a qualquer cargo da administração direta ou indireta, bem como das concessionárias de serviços públicos; negar ou obstar emprego em empresa privada; recusar ou impedir acesso 
a estabelecimentos comerciais em geral, negando-se a servir, atender ou receber cliente; ou comportamentos similares em hotéis, restaurantes, transporte público, arenas esportivas, salões de beleza; impedir acesso a prédios ou elevadores; impedir acesso às forças armadas, estabelecimentos educacionais; e impedir ou bloquear, de qualquer maneira, casamento ou convivência familiar. A Lei Caó é mais extensa e específica que a Lei Afonso Arinos de 1951, e as punições variam entre um e cinco anos de prisão.

Em 1990, a Lei $n^{\circ} 8.081$ modificou a Lei ${ }^{\circ} 7.716$, aprovada no ano anterior, incluindo o tipo penal "praticar, induzir ou incitar, pelos meios de comunicação social ou por publicação de qualquer natureza, a discriminação ou preconceito de raça, por religião, etnia ou procedência nacional”, com pena variando entre dois e cinco anos de prisão. (BRASIL, 1990)

A Lei Paim alterou a Lei Caó, em 1997, ao especificar que qualquer crime com base em raça, etnia, religião, cor ou origem nacional poderia ser punido com pena de um a três anos de prisão e multa. (BRASIL, 1997) As modificações foram principalmente processuais, reduzindo a pena para o crime de expressões racistas para de um a três anos de prisão e alterando a definição de crimes contra a honra ao incluir o crime de injúria racial. (BRASIL, 1940, art. 140, $\S 3^{\circ}$ ) O insulto racial difere do crime de racismo porque pune o dano contra a dignidade individual. Já o crime de racismo apena o dano causado a um número indeterminado de pessoas da mesma raça ou cor. Por essa razão, ao contrário do crime de dano individual de insulto racial, o crime de racismo, que afeta uma coletividade, não está sujeito à prescrição e é inafiançável. Nos casos de insulto racial, o juiz pode, discricionariamente, suspender a aplicação da pena de um a três anos, e há um período prescricional de oito anos. (MEYER-PFLUG, 2009, p. 102-103)

$\mathrm{Na}$ esfera cível, a regra geral de Direito Civil de responsabilidade por danos morais pode ser aplicada em casos de discriminação racial (os danos morais compensam o prejuízo causado pelo sofrimento psíquico ou o transtorno emocional, pelo dano à honra ou reputação). $\mathrm{O}$ artigo $5^{\circ}$ da Constituição Federal prevê indenização por danos materiais, morais ou à imagem. Além disso, o artigo 186 c/c 927 do Código Civil diz que aquele que, por ação ou omissão voluntária, negligência ou imprudência, violar direito e causar dano a outrem, ainda que exclusivamente moral, comete ato ilícito e fica obrigado a repará-lo.

A despeito da grande variedade de leis antidiscriminação, são poucas as questões levadas ao judiciário, apesar da existência de delegacias de polícia 
específicas para investigar e aplicar tais regras. (INTER-AMERICAN COMMISSION ON HUMAN RIGHTS, 1997) As pesquisas têm mostrado que apenas uma pequena porcentagem dos casos de discriminação chega às instâncias mais altas e que as ocorrências são frequentemente rechaçadas pelos agentes policiais. Uma pesquisadora brasileira sugere a tese de que o sistema legal tende a tratar o racismo e a discriminação como casos raros e isolados e não como parte de um padrão social mais amplo. (MARINHO, 1999) De tal modo, muitos advogados e defensores dos direitos civis têm apontado ambiguidades legais e a recusa das instâncias superiores de julgar esses casos.

Ao analisar a legislação antidiscriminação brasileira, antes de ser indicado para ser o primeiro ministro negro do Supremo Tribunal Federal, Joaquim Barbosa criticou a falta de efetiva observância da lei por parte do Ministério Público Federal. Ele atribuiu a ineficácia do Ministério Público à falta de organização, ao caos financeiro e também às lutas ideológicas internas. (GOMES, [200-]) Para Barbosa, a falta de envolvimento do Ministério Público tem sido encorajada pelos tribunais e o sistema judicial brasileiro e, em geral, reflete "o individualismo exacerbado, o extremo formalismo, a falta de racionalidade e o caráter prático na grande maioria das ferramentas disponíveis etc.” Ele completa que "diante do contexto, não é surpreendente que a situação geral das ações civis públicas é tão ruim que não existe nada para ser analisado no que diz respeito à proteção dos direitos das minorias por parte do Ministério Público!” (GOMES, 1999, p. 15-25) Desde que se tornou ministro do Supremo Tribunal Federal, Joaquim Barbosa tem apontado que "o mito da democracia racial impede que pessoas levem casos ao judiciário. As poucas pessoas que recorrem ao Ministério Público encontram agentes prontos para concluir que os cidadãos não estão apresentando um caso válido.”3

À luz da percebida ineficácia da legislação contra a discriminação no Brasil, muitas ONGs têm dedicado esforços para reformar a legislação de direitos civis. Uma conferência realizada em Brasília, em 2000, pelo advogado do Escritório Nacional Zumbi dos Palmares, Sérgio Martins, voltou as atenções para o desenvolvimento de mecanismos de combate ao racismo e à discriminação. Outras ONGs no Brasil, como o Centro de Articulação de Populações

3 Entrevista com Joaquim Barbosa, 14 de maio de 2007, p. 2 (transcrição em posse de Tanya K. Hernández). 
Marginalizadas (CEAP), têm funcionado como grupos que trabalham pela reforma da legislação antidiscriminação. ${ }^{4}$

Há indícios de que, à exceção dos ativistas que lutam pelos direitos civis, muitos profissionais do direito consideram a legislação antidiscriminação algo periférico. Poucos advogados consideram proveitoso ajuizar ações contra a discriminação racial, por temerem que tais ações sejam facilmente desconsideradas. A combinação da falta de conscientização geral sobre os direitos contra a discriminação com a relutância por parte dos profissionais do direito em aceitarem tais tipos de casos, e com a dificuldade de encontrar auxílio legal, provavelmente, faz com que milhares de casos de discriminação racial deixem de ser denunciados todos os anos. (JUSTICE STUDIES CENTER OF THE AMERICAS, 2004)

Contudo, há notícias de decisões judiciais em casos de discriminação contra a população afrodescendente, nos últimos anos, em várias áreas, incluindo na área penal, cível e em análises judiciais de programas de ação afirmativa. Além disso, pela primeira vez, estão sendo realizados estudos exploratórios do tratamento judicial de réus em casos criminais, assim como estudos da situação de mulheres negras no mesmo contexto. Como exemplo, o Instituto do Negro Padre Batista, no estado de São Paulo, foi criado através de um acordo com o procurador-geral do Estado, com o fim de ajuizar demandas penais. Pelo acordo, o procurador encaminhará para esse instituto todos os casos de racismo e injúria racial que ocorrerem no estado de São Paulo. Em 2004, o instituto só tinha, aproximadamente, 100 casos; um número baixo para o tamanho da população de afrodescendentes em São Paulo. Apenas algumas organizações representam afrodescendentes em demandas judiciais, uma delas o Instituto da Mulher Negra Geledés.

Fatores que contribuem para essa situação incluem a falta de uma consciência pública que permitisse que esses problemas pudessem ser resolvidos e a reduzida confiança na capacidade de o sistema judicial resolver tais casos adequadamente. Outro fator é que as delegacias policiais, aonde as vítimas devem se dirigir para registrar a ocorrência, frequentemente, não lidam com as referidas ocorrências de maneira séria ou dão informações inadequadas de como as vítimas devem proceder. As ações das delegacias de polícia mostram que a 
aplicação da legislação antirracismo encontra sérios problemas desde sua aprovação. Um estudo empírico demonstra deficiências graves nas respostas de organismos públicos às reclamações de racismo, que tendem a ser consideradas simples questões de honra, mesmo quando envolvem a proibição de acesso a transportes, direitos trabalhistas e proteção ao consumidor. (GUIMARÃES, 1998, p. 47) Um autor afirmou que "como resultado, advogados negros, com razão, reclamam sobre o real aumento de casos contra honra denunciados à polícia”. (GUIMARÃES, 1998, p. 47)

No estado do Rio de Janeiro há um órgão público chamado Disque Racismo, que lida com as demandas judiciais por racismo. Muitas das situações observadas em São Paulo são também comuns no Rio de Janeiro. Por exemplo, membros do Disque Racismo enfatizam a dificuldade em obter resultados favoráveis em demandas judiciais por racismo. Nos quatro anos após a inauguração do programa, em 1999, a organização obteve apenas três condenações. (JUSTICE STUDIES CENTER OF THE AMERICAS, 2004, p. 18) No contexto civilista latino-americano, como o do Brasil, cujos juízes decidem os casos, e não o júri, a baixa taxa de condenações reflete o ceticismo judicial no que diz respeito às demandas por discriminação.

Apesar disso, há uma tomada de consciência sobre as ferramentas legais antidiscriminação, como evidenciado pelo crescente número de ações ajuizadas. Só na Bahia, 220 pessoas ajuizaram ações por discriminação racial entre janeiro e outubro de 2008. O número contrasta nitidamente com o total de 308 casos levados ao Ministério Público da Bahia nos últimos 10 anos. (RACISMO..., 2008) No entanto, a grande maioria das demandas ajuizadas não obteve êxito. Um estudo das ações entre os anos de 2005 e 2006 revelou que apenas 32,9\% dos autores foram bem-sucedidos em suas demandas. (MENEZES, 2008) Similarmente, um estudo das ações julgadas nos anos de 2007 e 2008, novamente, revelou que apenas 30\% dos autores obtiveram êxito. (PAIXÃO et al., 2010, p. 264) Dificuldade similar é encontrada por autores de ações de discriminação no ambiente de trabalho nos Estados Unidos, onde 94\% das ações ajuizadas nunca vão a julgamento. Mais de $40 \%$ das ações de discriminação no ambiente de trabalho nos Estados Unidos são arquivadas antes do julgamento, e outros $54 \%$ dos autores frequentemente recebem apenas quantias simbólicas em acordos extrajudiciais. Os $6 \%$ restantes vão a julgamento, mas apenas uma em cada três ações tem chances de vitória. (NIELSEN; NELSON; LANCASTER, 2010, p. 175-201) 
Outro fator que impede a efetiva aplicação das leis antidiscriminação é a demanda por provas diretas de preconceito racial em vez de provas indiretas, como estatísticas que mostram os padrões das disparidades raciais. Um relatório do Centro de Estudos da Justiça das Américas sobre o sistema judicial brasileiro indica que a maioria das decisões judiciais no país exigem provas diretas da discriminação. (JUSTICE STUDIES CENTER OF THE AMERICAS, 2004) Esse é um critério de prova mais exigente, que torna mais difícil vencer o caso. Com efeito, conforme o critério da discriminação direta, o autor deve basicamente demonstrar a existência de três elementos diferentes: o ato discriminatório, o prejuízo causado pelo réu ao autor e a relação causal entre a discriminação racial e o ato discriminatório. Isso, portanto, requer que o acusado tenha intenção explícita de discriminar. Tal exigência é extremamente difícil de satisfazer em uma sociedade que se identifica como uma democracia racial e, por essa razão, não vê racismo nos usos corriqueiros das expressões que rebaixam o negro na sociedade.

A interpretação restritiva ou formalista do direito também impede a apresentação de ações de discriminação direta nos tribunais. Por vezes, os magistrados exigem que certo comportamento ou expressão, para ser qualificado como imputável, seja diretamente voltado contra uma pessoa de ascendência africana. Nesse sentido, por exemplo, um juízo determinou que chamar alguém de prostituta, vagabundo ou macaco não constitui racismo, uma vez que pessoas brancas também poderiam ser descritas dessa maneira. Assim, o judiciário ignora estereótipos culturais que associam negritude à prostituição, preguiça e qualidades de animais. Além do mais, a sentença veiculava o mito da "democracia racial" ao afirmar que, no Brasil:

as pessoas com pele mais escura podem até ser os ídolos de pessoas com pele mais clara nos esportes e na música, e as mulheres que são popularmente conhecidas como 'mulatas' parecem orgulhosas dessa condição e são exibidas com grande sucesso em muitos lugares famosos e populares. No Brasil, pessoas 'brancas' se casam regularmente com pessoas 'negras' e têm filhos [...]. Aqui não temos o racismo rigoroso e cruel observado em outros países, onde não-'brancos' são segregados, separados e não têm os mesmos direitos. Isso é racismo. (GUIMARÃES, 1998, p. 35)

Em alguns casos envolvendo ações ou expressões dirigidas a uma pessoa afrodescendente específica, o judiciário tem decidido que isso não representa 
um comportamento racista porque não prova que o preconceito ou intenção de discriminar foi dirigido contra a população afrodescendente como um todo. Por exemplo, no estado de São Paulo, a existência do crime de racismo não foi aceita pelo juízo em um caso em que o réu, um prefeito, disse a um funcionário da prefeitura por ocasião de sua demissão: "marginais e negros sujos não trabalharão mais aqui durante meu mandato”. A decisão afirma “dizer que uma pessoa particular é um ‘negro sujo’ ou que a administração municipal não os admitirá mais para o trabalho não constitui o crime (de racismo)”. O juízo completa que:

Discriminar, de acordo com o significado do próprio verbo, envolve proibir certas raças ou pessoas de certas religiões ou de certas cores de fazer uso de alguns direitos ou oportunidades que são conferidas a alguns segmentos da população. Isso não inclui exonerar alguém (em um lugar que muitos outros negros certamente continuam trabalhando) afirmando rudemente que a pessoa é um 'negro sujo', pelo menos para fins de configuração do crime previsto no artigo 20 da lei em questão [Lei 7.716/89, contra o racismo].

O juiz também concluiu que "como resultado, não há provas de uma oposição geral à raça negra na declaração do acusado, mas de um ataque verbal voltado exclusivamente à vítima e nada mais, porque, é importante notar, muitos negros continuam a servir a municipalidade (em questão)”. O tribunal concluiu que, no máximo, pode ter havido um crime de injúria; por essa razão o caso não pôde prosseguir e foi arquivado. ${ }^{5}$

O judiciário brasileiro tem feito pouco uso do critério de discriminação indireta, pelo qual o caráter discriminatório de um comportamento pode ser determinado pela presença de provas circunstanciais. Em tal caso, o autor deve provar que a vítima é parte de grupo específico (racial, nesse caso) e que ela recebeu tratamento diferente (inferior) do que o recebido por uma pessoa que não pertence ao grupo específico, independentemente da existência de manifestação explícita de intenção racista. O princípio da discriminação indireta parece ser aplicado apenas em casos de racismo ligados aos direitos dos consumidores. Esse critério tem sido usado para punir a discriminação praticada durante o acesso a clubes sociais ou no tratamento conferido a afrodescendentes em bancos. Em um exemplo, do primeiro caso, um magistrado decidiu que houve discriminação em uma casa 
noturna: o local tinha duas filas, uma supostamente para membros e outra para não membros; embora, na prática, os brancos da primeira fila podiam ingressar no local, enquanto os afrodescendentes da outra fila eram impedidos de comprar ingresso. O entendimento no caso foi o de que houve tratamento discriminatório contra membros de um grupo a despeito da falta de intenção discriminatória direta. ${ }^{6} \mathrm{Na}$ seara dos direitos do consumidor, um caso bem conhecido envolvendo um cliente negro que, ao tentar transferir uma pequena quantidade de dinheiro de sua conta bancária para a conta bancária da sua mulher, foi submetido a um longo e complexo interrogatório que excedeu em muito práticas bancárias corriqueiras para os clientes brancos. O órgão julgador também concluiu que tal comportamento foi racialmente motivado. (RACUSEN, 2002)

Como a tradição legal brasileira busca criminalizar o racismo e a discriminação racial (SILVEIRA, 2006), há uma tentativa de ampliação dos mecanismos para lidar com a discriminação. Em julho de 2010, o Brasil aprovou o Estatuto da Igualdade Racial. O Estatuto obriga o governo federal a administrar programas e adotar medidas específicas para reduzir a desigualdade racial. (BRASIL, 2010a) $\mathrm{O}$ artigo $1^{\circ}$ define que o estatuto é "destinado a garantir à população negra a efetivação da igualdade de oportunidades, a defesa dos direitos étnicos individuais, coletivos e difusos e o combate à discriminação e às demais formas de intolerância étnica”. É digno de nota que se trata da primeira legislação integral de promoção da igualdade racial na América Latina, com a articulação de metas governamentais para a promoção da inclusão racial e o desenvolvimento de políticas de ação afirmativa destinadas ao enfrentamento das desigualdades étnicas no tocante à educação, cultura, esporte e lazer, saúde, segurança, trabalho, moradia, meios de comunicação de massa, financiamentos públicos, acesso à terra, à justiça e outros. (BRASIL, 2010a, art. 4) O artigo 51 da lei cria Ouvidorias Permanentes para a Defesa da Igualdade Racial para receber e encaminhar reclamações de discriminação e monitorar a implementação de medidas de promoção da igualdade. Todavia, o estatuto tem sido criticado por ativistas afro-brasileiros por expressar simples aspirações e não proporcionar direitos concretos para garantir a igualdade nos moldes de políticas de ação afirmativa obrigatórias. (ALVES, 2010)

No resto da América Latina, as vítimas de discriminação racial podem recorrer apenas a princípios constitucionais genéricos de igualdade. Ainda que 
poucos advogados tenham tentado apresentar demandas de discriminação racial conforme a provisão genérica de igualdade constitucional, a medida judicial do amparo dá a possibilidade de se desenvolver uma estratégia judicial em favor da promoção da justiça social.

\section{O uso do amparo constitucional na América Latina}

Na América Latina, há uma poderosa fonte de efetivação constitucional: o recurso judicial do amparo (de nome alternativo, tutela). Amparo é uma ação constitucional que permite aos demandantes proteger seus direitos constitucionais e direitos humanos com uma variedade de medidas judiciais similares (incluindo liminares, sentenças declaratórias e mandados). Em todos os países latino-americanos, exceto a República Dominicana (e o Brasil), o amparo é previsto nas constituições nacionais. (BREWER-CARÍAS, 2009) Amparo é considerado um recurso extraordinário que deve ser usado apenas quando nenhuma outra medida judicial está disponível para a imediata proteção dos direitos humanos. Contudo, mais importante, trata-se de um direito pessoal de ação que qualquer indivíduo que tenha sofrido dano tem legitimidade para usar. Existe também uma tendência crescente de empregar o amparo para proteger direitos coletivos por meio da petição de alguém que tenha sofrido algum dano. Quatro países não autorizam o uso do amparo contra particulares, apenas contra autoridades públicas: El Salvador, Guatemala, México e Panamá. Em contraste, 10 países (Argentina, Bolívia, Chile, Costa Rica, República Dominicana, Nicarágua, Paraguai, Peru, Uruguai e Venezuela) autorizam ações de amparo contra particulares. Devido ao fato de que o amparo é fundamentalmente um direito pessoal de ação para proteger direitos constitucionais, a decisão de um tribunal somente vincula as partes da ação, e no que diz respeito à demanda apresentada. Não tem valor formal como precedente e, portanto, é limitada por sua incapacidade de produzir efeitos declaratórios gerais sobre alguma disposição legal atacada. Apesar disso, as decisões em sede de amparo podem informalmente gerar um efeito similar ao do precedente, pelo qual uma sucessão de decisões de amparo por parte dos mesmos juízes, rejeitando a aplicação da mesma lei com base em fatos bastante similares, aumenta a probabilidade de uma relativa uniformidade.

Um exemplo de um bem-sucedido uso do amparo para fazer avançar a igualdade racial ocorreu no caso de Liliana Cuellar Sinisterra, uma cidadã 
colombiana de ascendência africana, que estava em Cartagena para uma viagem de negócios representando o escritório de Houston da Deloitte and Touche. ${ }^{7}$ Em 2 de julho de 2005, Sinisterra teve acesso negado a uma casa noturna por causa da cor de sua pele. A vítima usou a tutela (equivalente colombiana à ação de amparo) para ajuizar uma ação contra a casa noturna que não permitira sua entrada, mas permitira a entrada de brancos. Com a tutela, ela ingressou com uma ação nos moldes do artigo 13 da Constituição colombiana, que protege a igualdade, a dignidade humana e a honra. Depois de perder no juízo municipal de Cartagena, Sinisterra apelou para a Corte Constitucional colombiana, e o tribunal reformou a decisão da tutela. A corte justificou a sua decisão com base no direito de não ser sujeito à discriminação racial ao tentar ingressar em lugares públicos e proibiu o estabelecimento de negar o acesso de pessoas por razões ilegais. Contudo, a despeito da existência do remédio judicial do amparo/tutela e do desenvolvimento de legislações domésticas antidiscriminatórias, há várias barreiras à efetiva aplicação de tais medidas na América Latina, como discutido na seção seguinte.

\section{O desafio de fazer cumprir as normas de dados raciais nos censos}

O legado e o apoio contínuo ao mito da democracia racial na América Latina têm interferido no reconhecimento de que recenseamentos com dados raciais podem auxiliar a promover a igualdade racial. Perguntas sobre identidade racial nos recenseamentos têm sido consideradas ato de discriminação. Ativistas que lutam pela justiça racial na América Latina questionam essa afirmação devido à urgente necessidade de demonstrar concretamente, com estatísticas, como atitudes sociais racializadas têm mantido os afrodescendentes em condição de subordinação.

Ainda que, nos diversos países, haja uma grande variação sobre aquilo que os juízes aceitam, em termos de dados provenientes das ciências sociais, como prova das desigualdades raciais em casos individuais de discriminação racial, a coleta sistemática de dados continua sendo útil. Isso porque denúncias individuais de discriminação podem ser apreciadas mais prontamente como discriminação quando os juízes estão expostos ao discurso público sobre a desigualdade racial generalizada, que contrasta com o mito da democracia racial. Além disso,

7 Tutela T-1250871; Corte Constitucional, sentencia T-131 del 23 de febrero de 2006, Liliana Cuéllar Sinisterra contra los establecimientos comerciales la Carbonera Ltda. y la discoteca Qka-Yito. 
a disponibilidade de dados raciais facilita a pressão por políticas governamentais de promoção da igualdade.

Por exemplo, devido ao fato de que o Brasil tem sido um dos poucos países da América Latina que incluiu de maneira regular uma questão de identificação racial nos censos decenais, suas organizações de justiça racial têm conseguido utilizar dados para apoiar suas reivindicações contra as inaceitáveis disparidades raciais no país. Em grande parte por essa razão, o Brasil é um dos poucos países da região a implementar políticas de ação afirmativa em concursos públicos e na área da educação.

Em contraste, como discutido no capítulo 2, a maioria dos países da América Hispânica e Caribe se recusaram firmemente a realizar recenseamentos com dados raciais. Todavia, esse quadro está lentamete começando a mudar. Ainda que a Venezuela tenha se recusado a coletar dados raciais nos seus censos desde 1873 (20 anos após a abolição da escravidão em 1854), em 2008 o governo anunciou que incluiria uma pergunta sobre raça no censo de 2010. Tal decisão foi resultado de um intenso lobby de organizações afro-venezuelanas com o suporte do Banco Interamericano de Desenvolvimento e do Banco Mundial. Através do financiamento, em 2000, de uma conferência internacional voltada para a necessidade de um recenseameno racial na região, o Banco Interamericano de Desenvolvimento e o Banco Mundial ajudaram muitos países latino-americanos a pressionarem politicamente seus governos. (POLITICAL..., 2000)

Além disso, o Banco Interamericano de Desenvolvimento tem ofertado um pequeno, mas crescente, número de empréstimos, para que os institutos nacionais de estatística realizem censos nacionais que melhorem a coleta de dados relacionados à raça e etnia. O Banco também tem ofertado auxílio técnico para financiar estudos específicos e pesquisas sobre raça e etnia. Agora os formulários dos censos da Colômbia, Cuba, Equador, El Salvador, Costa Rica, Porto Rico e Venezuela explicitamente contam afrodescendentes. Guatemala, Honduras e Nicarágua contam os afrodescendentes por meio da introdução de uma pergunta sobre ancestralidade étnica garifuna. Infelizmente, um acompanhamento feito em 2002 pelo Banco Interamericano de Desenvolvimento revelou que avanços têm sido notados na coleta de dados sobre indígenas, mas muito pouco na coleta de dados sobre afrodescendentes. (MAZZA, 2002, p. 3-5) Até que mais países na região se comprometam a solicitar dados raciais nos censos, afrodescendentes continuarão a lutar para tornar suas necessidades visíveis no discurso público e tangíveis nos tribunais. 
Enquanto alguns países aceitaram a demanda por dados raciais nos censos, outros governos recusaram tal demanda sob o argumento de que a fluidez das identidades raciais na América Latina compromete a possibiliade de coletar dados raciais. A afirmação do governo é equivalente a dizer: "como realmente podemos saber quem é negro?”. De fato, é verdade que aspectos demográficos e a ideologia racial na América Latina dissuadiram muitas pessoas de ancestralidade africana de se identificarem como negras. Todavia, o crescimento dos movimentos negros de justiça social na América Latina demonstra que a fluidez racial em termos de identidade pessoal não precisa conflitar com o entendimento político de hierarquia e disparidade racial. Certamente, a capacidade de um país multirracial, como o Brasil, de coletar dados raciais por décadas demonstra que outros países latino-americanos também podem fazê-lo.

Por exemplo, a despeito do fato de que o Equador reinseriu uma questão racial no censo apenas em 2011, quase 5\% da população se identificou como negro ou mulato. Além disso, quando o órgão recenseador realizou, em 2004, uma pesquisa sobre emprego com uma pergunta sobre racismo, a maioria dos afro-equatorianos afirmou saber o que era racismo, em contraste com a pequena porcentagem dos entrevistados indígenas que afirmaram o mesmo. (BECK; MIJESK; STARK, 2011) Essa pesquisa confirma um estudo de afro-equatorianos realizado em 2002, em Quito, o qual revelou que os entrevistados tinham consciência racial e percebiam o racismo e o preconceito nas suas comunidades e vida cotidiana. (DE LA TORRE, 2002) Similarmente, na Cuba atual, a despeito da retórica unificadora do patriotismo socialista e da democracia racial, categorias raciais são entendidas como elementos importantes para a compreensão da estratificação social. (SAWYER, 2006) Em outras palavras, o legado da democracia racial não precisa continuar obstruindo o reconhecimento da diferença e disparidade racial enquanto o sistema jurídico dispõe do suporte apropriado para lidar efetivamente com tais demandas.

\section{O desafio de fazer valer o Estado de Direito}

A reforma do sistema jurídico, com o objetivo de aumentar sua estabilidade, tem sido uma preocupação de longa data na América Latina. Em particular na década de 1980, quando se iniciou um intenso período de reforma judicial. (ÁLVAREZ, 1991) Projetos de reforma tentaram aumentar a qualificação dos servidores do judiciário, aumentar os orçamentos do judiciário e melhorar os 
padrões da carreira no judiciário. As prioridades da reforma judicial foram estabelecidas como uma resposta às avaliações dos países, os quais indicavam que juízes tinham acesso negado a recursos como treinamento, pessoal de apoio, materiais jurídicos básicos, códigos atualizados, instalações apropriadas e salários dignos. Além do mais, as avaliações mostraram que juízes sofriam, frequentemente, com influências políticas, conflitos de interesse e muita corrupção.

Desde aquele tempo, o judiciário na América Latina ainda é percebido por muitos usuários como uma instituição em crise (DAKOLIAS, 1996, p. 1) e os países da região consideram a reforma judicial uma prioridade. (BIEBESHEIMER, 2001, p. 99) Pesquisas de opinião, rotineiramente, demonstram que cidadãos têm pouca expectativa de receber tratamento justo nos sistemas judiciais latino-americanos, e de que essas instituições são as menos respeitadas nos setores público e privado. (HAMMERGREN, 1998, p. 4) A corrupção continua ocorrendo de maneira descontrolada porque o judiciário não tem autonomia financeira. Além do mais, enquanto o público geral percebe o processo de indicação ao judiciário como político, secreto e, portanto, isento de controle público, os cidadãos com menor renda têm particularmente um baixo nível de confiança no sistema judicial. Consequentemente, um número crescente de países latino-americanos instituíram a vitaliciedade e outras medidas de segurança para blindar os juízes da influência política. (SUTIL, 1999, p. 255-277)

Entretanto, recentemente acadêmicos começaram a questionar a imagem disseminada da América Latina como uma região "juridicamente falida”, uma vez que o discurso sobre a região, que transmite a imagem de formalismo desnecessário, ineficiência e corrupção, aplica-se a todos os sistemas jurídicos em graus diferentes. Jorge Esquirol, particularmente, identifica a promoção da imagem de uma América Latina juridicamente falida como um mecanismo para justificar mudanças nas políticas públicas, com inspiração neoliberal, sem maiores reflexões sobre os efeitos de tais mudanças nas populações marginalizadas. (ESQUIROL, 2008, p. 75-124) Por exemplo, com o discurso da "região juridicamente falida", muitas das históricas proteções que os códigos trabalhistas latino-americanos tinham concedido aos trabalhadores foram flexibilizadas. A alegação de "região juridicamente falida" favorece a privatização em larga escala e fragiliza o poder de os governos promoverem justiça social. Isso leva Esquirol a alertar as populações subordinadas sobre 
necessidade de não descartar o direito latino-americano como possibilidade de promoção da justiça social.

Apesar disso, para que as reformas de direito civil alcancem o máximo de eficácia, é preciso que seja levado em consideração o preconceito racial inconsciente dos juízes. (HAMMERGREN, 1998, p. 31) De fato, a existência de um violento sentimento contra a população negra e a população indígena no contexto social da América Latina e Caribe pode fazer que os juízes, inconscientemente, considerem os direitos civis meramente simbólicos, e não como um "direito para valer" que deve ser rigorosamente aplicado. (WHITE, 2003, p. 785873) Analistas apontam que a discriminação racial e o preconceito de classe ainda são fortes no sistema jurídico latino-americano. (BRYSK, 2000, p. 258) Para que os direitos civis sejam importantes na América Latina, educar o judiciário sobre a existência da discriminação e das limitações das normas de direitos civis se faz necessário. Além do mais, o contexto mais amplo de reforma judicial deve lidar com o fato de que, historicamente, "garantias constitucionais, frequentemente, têm oferecido, na prática, pouca ou nenhuma proteção para grupos vulneráveis", e que "elites poderosas tendem a operar 'acima' ou 'fora' do direito, a impunidade é generalizada e os poderosos fora da lei raramente são enquadrados nos rigores da lei”. (SIEDER, 2001, p. 142, 151) Considerando que apenas o texto das normas de direitos civis não é suficiente para mitigar a má influência do preconceito judicial, talvez a principal maneira de neutralizar tais efeitos seja interferir diretamente nos cursos de formação do judiciário. Isso poderia ser implementado por meio de escolas de formação do judiciário que têm surgido na América Latina com as primeiras iniciativas dos esforços modernos de reforma judicial.

Ademais, as aulas de formação do judiciário poderiam tratar também da importância de considerar dados das ciências para avaliar denúncias de discriminação (GASTWIRTH, 2000), já que os juízes não estão acostumados a ouvirem argumentos baseados em dados científicos. (COOK, 1999, p. 109115) Isso se deve, em parte, ao fato de que a formação jurídica latino-americana ocorre na graduação, em departamentos separados dos departamentos das ciências sociais das universidades. (PÉREZ-PERDOMO, 2006, p. 1049) Além do mais, como muitos professores de direito latino-americanos exercem outras carreiras jurídicas em tempo integral e ensinam em tempo parcial, em geral, não publicam pesquisas nem realizam estudos interdisciplinares. Essa situação é radicalmente oposta à realidade estadunidense, onde os estudos jurídicos fazem 
parte de um programa de pós-graduação antecedido por uma formação de quatro anos em nível de graduação, que pode ser na área de ciências sociais ou em outros cursos que o estudante prefira. Os cursos de direito nos Estados Unidos são oferecidos por professores de direito contratados não somente por suas habilidades de ensino, mas também por sua dedicação à pesquisa e à produção acadêmica, a qual pode ter natureza interdisciplinar.

Felizmente, a emergência de uma comunidade latino-americana de advogados dedicados ao interesse público começou a ampliar as possibilidades de qual tipo de prova é apropriada em juízo. (SUTIL, 1999, p. 255-277) As faculdades de direito na região aos poucos têm começado a incluir cursos voltados ao interesse público em seus currículos. Por exemplo, cursos sobre discriminação racial são oferecidos em escolas de direito na Argentina, Chile, Colômbia, Equador, Peru e Porto Rico. ${ }^{8}$ Há ofertas de cursos mais gerais sobre discriminação em várias escolas de direito na Argentina e no Equador. ${ }^{9}$ Escolas de direito mexicanas e venezuelanas oferecem cursos sobre direitos sociais e igualdade. ${ }^{10}$

8 Esses cursos incluem: Universidad Nacional de Córdoba (Argentina), Derechos Humanos UNIDAD III-Curso de Derechos Civiles y Políticos (en los que se incluye antidiscriminación), y Derechos Humanos UNIDAD VII - Curso de Fuentes de Derecho Internacional contra la Discriminación. Disponível em: <http://goo.gl/ti7eRp>; Universidad la República, Facultad de Derecho (Chile): curso Daños por discriminación. Disponível em: <http://goo.gl/Oqto6x>; Universidad del Cauca-Facultad de Derecho y Ciencias Políticas y Sociales (Colombia), curso Derecho de los Grupos Étnicos. Disponível em: <http://goo.gl/jtqnhG>; Facultad de Derecho de la Pontificia Universidad Católica del Perú, Curso sobre la igualdad en el empleo y la lucha contra la discriminación. Disponível em: <http://goo.gl/1sUC7W>; Facultad de Derecho Eugenio María de Hostos (Puerto Rico), curso de Discriminación en el empleo. Disponível em: <http://goo.gl/5MahKD>; y Facultad de Derecho de la Universidad Interamericana de Puerto Rico, curso de Discriminación en el Empleo. Disponível em: <http://goo.gl/L6K8Vx>.

9 Esses cursos incluem: Facultad de Derecho de la Universidad de Mendoza (Argentina), Derechos humanos y trabajo social (incluyendo la acción afirmativa). Disponível em: <http://goo.gl/IBMjRi>; Facultad de Derecho de la Universidad de Palermo (Argentina), curso Derechos Sociales (incluyendo la exclusión social y la desigualdad). Disponível em: <http://goo.gl/azM4qa>; Facultad de Derecho de la Universidad Nacional de Córdoba (Argentina), curso Desigualdad social y acceso a la justicia. Disponível em: <http://goo.gl/xwbYsM>; Facultad de Derecho de la Pontificia Universidad Católica del Ecuador, curso de Teoría y práctica de los derechos humanos (incluyendo la acción afirmativa y la exclusión social). Disponível em: <http://goo.gl/1TdXOH>.

10 Esses cursos incluem: Facultad de Derecho de la Universidad La Salle Pachua (México), curso Garantías individuales y derechos de los grupos vulnerables. Disponível em: <http://goo.gl/eOxK3d>; Facultad de Derecho de la Universidad Nacional Autónoma de México, curso Ética y derechos humanos (incluyendo derecho a la igualdad). Disponível em: <http://goo.gl/y9nB2r>; Universidad Panamericana-Facultad de Derecho (México), Seminario de Derechos Humanos: Igualdad y Antidis- 
Além do mais, praticamente todas as escolas de direito latino-americanas oferecem cursos em direitos humanos e suas fontes no direito internacional.

Uma dificuldade que continua limitando o acesso ao judiciário é a concentração de escritórios jurídicos em áreas urbanas. O Ministério Público e outros advogados públicos estão lotados principalmente em áreas urbanas. Esse sistema impede que boa parte da população rural negra tenha acesso aos serviços jurídicos. (GARRO, 1999, p. 278-301) México e Guatemala estão entre os poucos países que instituíram advogados públicos para comunidades rurais. (PLANT, 1999)

A alternativa de contratar um advogado particular é, de modo similar, dificultada pelo número limitado de advogados particulares em áreas rurais e também pela dificuldade de os possíveis autores conseguirem demonstrar a probabilidade de ganharem a ação, o que poderia lhes conferir a oportunidade de litigar sem os custos de administração judicial. Se não é possível vislumbrar chances de vitória no início do caso, os advogados particulares ficam menos inclinados a aceitar advogar em "novidades", como as ações por discriminação. Além do mais, somente aqueles autores que podem se beneficiar da assistência judiciária gratuita estão isentos do pagamento dos honorários advocatícios e das custas processuais. Essa prática contrasta com o sistema legal estadunidense, no qual as partes derrotadas não são automaticamente obrigadas a arcar com o ônus da sucumbência, exceto quando autorizado por lei. Por exemplo, o título VII da Lei dos Direitos Civis de 1964 autoriza que a parte autora vitoriosa solicite o reembolso dos honorários advocatícios em ações por discriminação no ambiente de trabalho. O réu, se vitorioso, só tem direito a receber honorários advocatícios se o autor "não for razoável, leviano, carente de mérito ou insultante”. (ESTADOS UNIDOS, 1978) Desse modo, apesar de existirem características estruturais projetadas para facilitar o acesso dos menos privilegiados ao judiciário na América Latina, os obstáculos para sua implementação limitam sua eficácia. Com todos esses obstáculos à aplicação da legislação antidiscriminação no âmbito nacional, os ativistas no campo da justiça social na região também se concentram na arena do direito internacional como uma

criminación (igualdad y no discriminación). Disponível em: <http://goo.gl/kKRzBR>; Facultad de Derecho de la Universidad Católica Andrés Bello (Venezuela), curso Condiciones sociales, económicas y políticas de acceso a la justicia. Disponível em: <http://goo.gl/V76k1W>. 
alternativa para o ajuizamento de ações e para o avanço de propostas de reforma no direito doméstico.

\section{O contexto internacional dos direitos humanos}

A maioria dos países latino-americanos é signatária da Convenção Internacional para a Eliminação de Todas as Formas de Discriminação Racial (Icerd). ${ }^{11}$ Essa situação contrasta com a posição dos Estados Unidos, que usou o direito de se reservar à aplicação da convenção. $\mathrm{O}$ artigo $6^{\circ}$ da convenção dispõe que "Os Estados-partes assegurarão, a qualquer pessoa que estiver sob sua jurisdição, proteção e recursos efetivos perante os tribunais nacionais e outros órgãos do Estado competentes, contra quaisquer atos de discriminação racial que, contrariamente à presente Convenção, violarem seus direitos individuais e suas liberdades fundamentais, assim como o direito de pedir a esses tribunais uma satisfação ou repartição justa e adequada por qualquer dano de que foi vítima em decorrência de tal discriminação". O órgão encarregado de fazer cumprir a convenção é o Comitê das Nações Unidas para a Eliminação da Discriminação Racial (Cerd).

Todos os países signatários da convenção são obrigados a submeter relatórios a cada dois anos ao Cerd, com o fim de detalhar como os direitos estão sendo implementados. A ONU avalia os relatórios e faz recomendações escritas ao Estado-parte. (UNITED NATIONS, 2006) A cada quatro anos o Conselho de Direitos Humanos das Nações Unidas também analisa os registros de direitos humanos de cada Estado-membro.

$\mathrm{O}$ artigo 14 da convenção estabelece um mecanismo de apresentação de denúncias de indivíduos e grupos que alegam ter sofrido danos por parte de um Estado-membro. Os denunciantes devem esgotar todos os mecanismos previstos no sistema doméstico. Uma vez recebida a denúncia, o comitê pode requisitar informações e fazer recomendações para o Estado-parte. O comitê da ONU se encontra duas vezes por ano em sua sede em Genebra, para analisar a documentação escrita das denúncias, e então faz recomendações aos Estados-membros.

11 Entre os países signatários latino-americanos estão: Bolívia, Brasil, Chile, Colômbia, Costa Rica, Cuba, República Dominicana, Equador, El Salvador, Guatemala, Honduras, México, Nicarágua, Panamá, Paraguai, Peru, Uruguai e Venezuela. Convención Internacional sobre la Eliminación de Todas las Formas de Discriminación Racial, 7 de marzo de 1966, en vigor desde el 4 de enero de 1969. Disponível em: <http://goo.gl/VtMq2q>. 
Ainda que os denunciantes não precisem viajar a Genebra para as audiências, as vítimas latino-americanas de discriminação racial geralmente não têm se servido da Icerd para fazer denúncias. Isso porque uma denúncia junto ao Icerd não pode ser considerada se a mesma situação estiver sendo investigada por meio de outro procedimento internacional. A via internacional escolhida tem sido a Comissão Interamericana de Direitos Humanos.

Assim como o comitê da ONU, a Comissão Interamericana de Direitos Humanos prepara relatórios sobre as condições dos direitos humanos no hemisfério ocidental. Além disso, recebe denúncias de indivíduos e organizações acerca de abusos de direitos humanos que violam a Convenção Americana de Direitos Humanos de 1969. A convenção assegura o direito à igualdade e à proteção judicial perante a violação de direitos fundamentais. Mas antes da realização de uma denúncia, o denunciante precisa esgotar todos os recursos legais disponíveis no país onde a violação ocorreu.

Os relatórios da comissão, com suas conclusões e recomendações, vinculam o Estado-membro investigado à medida que o obriga a responder ao relatório para esclarecer e indicar como pretende melhorar a situação. Então, a comissão decide quais denúncias devem ser apresentadas à Corte Interamericana de Direitos Humanos, na Costa Rica. A corte é autorizada a obrigar os Estados a reformarem suas leis ou adotarem outras medidas para lidar com as denúncias. Uma vez que a corte prolata a sentença, a Organização dos Estados Americanos (OEA) pode monitorar o efetivo cumprimento da decisão.

Infelizmente, nota-se que a OEA tem se autolimitado a receber os relatórios e deixado de fazer investigações autônomas para o acompanhamento do efetivo cumprimento das decisões. (GLOBAL RIGHTS PARTNERS FOR JUSTICE, 2004) Além do mais, a Corte Interamericana e a Comissão Interamericana não dispõem de meios de coerção direta pelos quais poderiam garantir a aplicação das suas decisões ou recomendações quando declaram que um Estado é responsável pela violação de direitos humanos, tampouco possui meios de obrigá-lo a tomar certas medidas de reparação à vítima. Entretanto, ignorar o pronunciamento legal que emana do sistema interamericano faz com que a reputação do país seja arranhada, gerando custos políticos. Em resumo, o valor do sistema interamericano reside na sua capacidade de conferir força política para aqueles que desejam modificar a situação.

Mais especificamente, o que tem sido considerado especialmente útil sobre o sistema interamericano é a atenção midiática e a consequente influência 
que as Organizações Não Governamentais conseguem angariar. Quando a Comissão Interamericana conduz uma visita ao local da denúncia para investigá-la ou preparar um relatório sobre o país, a comissão realiza encontros com agentes públicos, forças armadas, autoridades responsáveis por centros de detenção, polícia, igrejas e organizações da sociedade civil. Desse modo, a mera presença da comissão em um país gera debate público sobre os direitos humanos. As organizações da sociedade civil possuem mais condição de demandar dos governos quando a Comissão Interamericana e a Corte Interamericana obrigam um Estado a investigar a violação e punir os responsáveis; a efetuar reparações pecuniárias ou simbólicas; a implementar as apropriadas reformas legislativas, administrativas ou de outra natureza para erradicar a prática que foi considerada como violadora de direitos humanos. Em particular, a demanda interamericana por reforma legislativa é especialmente útil naquelas nações sem legislação interna efetiva para tratar da discriminação racial.

Para complementar o sistema interamericano, em 2004, a Comissão Interamericana criou uma relatoria sobre os Direitos de Afrodescendentes e contra a Discriminação. O objetivo central é ter um relator especial trabalhando juntamente aos Estados membros da OEA para aumentar a conscientização sobre o dever dos Estados de respeitar os direitos humanos de afrodescendentes e trabalhar para a eliminação de todas formas de discriminação racial, analisar os desafios atuais que os Estados da região enfrentam no que diz respeito ao racismo, formular recomendações voltadas à superação dos obstáculos, identificar e compartilhar as melhores práticas na região e monitorar e fornecer assistência técnica requerida pelos Estados-membros na implementação das recomendações na prática e no direito nacional. O trabalho do relator pode dotar as ONGs com dados específicos sobre a existência de discriminação racial em vez de tais dados serem agregados a um relatório geral sobre direitos humanos.

Consequentemente, o relatório abre caminhos para que as demandas por reformas raciais sejam mais influentes politicamente. Um exemplo útil é o relatório nacional realizado em 2009 sobre a situação da discriminação racial na Colômbia. (INTER-AMERICAN COMMISSION ON HUMAN RIGHTS, 2009) O informe do relator, inequivocamente, declara que as leis colombianas sancionadoras da discriminação racial são insuficientes para erradicar a vasta disparidade racial que existe no país. Portanto, o relator insta o governo a se engajar ativamente e a apoiar políticas voltadas a diminuir a exclusão social e as disparidades raciais. Em resumo, o enfoque especializado do relator facilita 
uma avaliação mais profunda de questões de discriminação racial. Com o advento do relator especial, as ONGs e as vítimas individuais de discriminação podem se colocar em melhor posição e utilizar as vias do direito internacional para lidar com questões de discriminação racial.

Apesar disso, o sistema interamericano tem sido difícil de ser acessado pelas vítimas de discriminação racial e seus mandatários por variadas razões. (GROSSMAN, 2008, p. 1267-1282) A exigência da Comissão Interamericana de que os requerentes esgotem as vias legais internas disponíveis no Estado onde a alegada violação ocorreu pode, inadvertidamente, dissuadir indivíduos de acionar o sistema. Pode parecer desalentador gastar verba para esgotar os recursos internos, que lidam inadequadamente com os danos causados pela discriminação racial, para só então despender ainda mais fundos para lançar mão do direito internacional.

Todavia, a Comissão Interamericana não exige o esgotamento dos recursos internos se a vítima teve acesso negado a tais recursos, se as leis locais não garantem o devido processo legal para a proteção dos direitos da vítima, quando o Estado causou atraso indevido, quando a pessoa não possui fundos para pagar por um advogado e o Estado não oferece o serviço gratuitamente ou quando os advogados do país em questão estão com medo de representar a vítima. Mas cada uma dessas exceções exige que a vítima arque com os custos para demonstrar a aplicabilidade da exceção e, assim, também representa um desincentivo para acionar o sistema. Além do mais, litigar na arena internacional é desafiador, por si só, porque o demandante tem o ônus da prova e, portanto, deve reunir provas significativas sobre o caso ou a situação. Dado que as reclamações podem ser enviadas via postal, e que os procedimentos se baseiam principalmente nos documentos escritos, os demandantes não precisam viajar para Washington, onde se encontra a sede da Comissão Interamericana, ou para a Costa Rica, onde se encontra a sede da Corte Interamericana. Apesar disso, devido à possibilidade de o processo no sistema interamericano durar vários anos, o denunciante deve estar preparado para enfrentar o processo por um longo período de tempo. Essa é uma limitação especialmente relevante, pois a corte interamericana tem a faculdade de solicitar a repetição de procedimentos já realizados na Comissão Interamericana se, segundo os critérios da corte, os procedimentos da comissão não atenderem aos seus padrões. ${ }^{12}$ A potencial necessi- 
dade de testemunhas viajarem para destinos internacionais distintos para prestar seus depoimentos aumenta o custo da litigância no sistema interamericano.

A despeito dos obstáculos no sistema interamericano de direitos humanos, ele continua sendo uma via alternativa promissora para lidar com casos de discriminação racial no hemisfério. É alentador que a Corte Interamericana tenha explicitamente declarado que uma concepção restritiva de direitos na seara doméstica não representa obstáculo para que o Estado tenha obrigações mais amplas na seara do direito internacional. ${ }^{13}$ De fato, o número de casos apresentados ao sistema interamericano tem aumentado bastante. Enquanto a Comissão Interamericana recebeu apenas 517 petições em 1998; em 2005, foram 1330 petições. ${ }^{14}$ Ainda mais significativas são as recentes decisões do sistema interamericano, indicando que está aberto para avaliar questões complexas envolvendo preconceito racial na região.

Por exemplo, em 2006, a comissão concluiu que o Estado brasileiro violara a obrigação de assegurar igualdade racial e o direito a um julgamento justo no caso de Simone André Diniz. (INTER-AMERICAN COURT OF HUMAN RIGHTS, 2004) No caso, Simone se candidatara a uma vaga de doméstica anunciada no jornal, a qual dizia que "brancos" tinham a preferência. Quando Simone, que é negra, ligou para obter informações sobre o emprego, perguntaram-lhe sobre a cor da sua pele e, quando ela se identificou como uma mulher negra, prontamente lhe foi dito que ela não atendia às exigências da vaga.

Contudo, quando Simone denunciou, para a polícia, a violação à lei brasileira contra discriminação racial, o Ministério Público, que é o responsável por denunciar tais crimes, se negou a oferecer a denúncia, sob a alegação de que não existia fundamento para afirmar que houve crime de racismo. Quando a recomendação do Ministério Público de arquivamento do caso chegou até o juiz, o mesmo ordenou o arquivamento da denúncia, a despeito das evidências de uma legítima acusação de racismo. A comissão, ao analisar as ações do Estado brasileiro, observou que o relatório Icerd 2004 apontou que o judiciário brasileiro tende a ser permissivo com a prática de discriminação racial, pois adota um padrão de arquivamento imediato de denúncias de discriminação racial, e que isso foi o que ocorreu no caso de Simone Diniz. Desse modo, a comissão concluiu

13 Case of the Mayagna (Suno) Awas Tingni Community v. Nicaragua, 2001 Inter-Am. Ct. H.R. (ser. C) $n^{\circ} 79$ (August 31, 2001).

14 Inter-Am. CHR, Annual Report, OEA/Ser.L/V/II.124, doc. 5, cap. 3, p. 8, 2006. 
que o Estado brasileiro violara a cláusula de igualdade prevista no artigo 24 da Convenção Americana de Direitos Humanos. As recomendações feitas pela comissão incluem indenizar Simone Diniz satisfatoriamente pela violação de direitos humanos, garantir assistência financeira para que ela possa melhorar sua formação, reformar a lei antirracismo para torná-la mais efetiva, conduzir uma investigação sobre os fatos alegados por Simone na denúncia arquivada e oferecer formação aos agentes policiais em como se comportar de maneira adequada para a aplicação da lei antirracismo.

Ainda que as recomendações da comissão não sejam obrigações jurídicas do Estado, a atenção pública que o relatório da comissão propicia teve uma influência no caso Diniz. À época do relatório anual da comissão, em 2010, foi apontado que o Estado brasileiro tinha parcialmente realizado as recomendações, uma vez que Simone Diniz tinha sido indenizada pelas violações aos direitos humanos e a responsabilidade do Estado pela violação havia sido publicamente reconhecida. Sem dúvida, o sistema interamericano é um processo demorado e de resultados ambíguos, mas o caso Diniz mostra que é possível pressionar para conseguir promover a causa da igualdade racial na América Latina.

Menos bem-sucedido, entretanto, foi um caso posterior, de Wallace de Almeida, um jovem soldado do Exército brasileiro que foi assassinado pela Polícia Militar do Rio de Janeiro no caminho de casa, no Morro da Babilônia. (INTER-AMERICAN COURT OF HUMAN RIGHTS, 2006) A comissão concluiu que o Estado brasileiro violou a obrigação de tratar todas as pessoas igualmente e sem discriminação perante a lei, trazida pelo artigo $24 \mathrm{da}$ Convenção Americana de Direitos Humanos. Vale ressaltar que a comissão destacou o fato de a polícia brasileira levar em conta o perfil racial das pessoas para, sistematicamente, lançar mão de táticas policiais violentas, com a presunção de que todos os moradores negros das favelas são necessariamente criminosos, caracterizando o fato como uma violação aos direitos humanos que o Estado brasileiro foi obrigado a investigar sem preconceito. Isso porque uma obrigação estatal, por força da convenção, estende-se não somente às ações diretas, mas também às demais autoridades públicas, tais como policiais, promotores e juízes. Consequentemente, a comissão recomendou que os parentes de Wallace de Almeida fossem indenizados pelo homicídio, que uma investigação completa e imparcial do assassinato se iniciasse com o objetivo de processar os criminosos, e que o Estado adotasse medidas para educar juízes e policiais para evitar discriminação racial nas operações da polícia, 
investigações, processos e condenações criminais. A disposição da comissão em identificar a discriminação racial como um fator causal da morte de Wallace de Almeida foi uma vitória significativa dos denunciantes. Infelizmente, mais de 10 anos depois do assassinato de Wallace, o Estado brasileiro ainda não cumpriu nenhuma das recomendações e a comissão continua monitorando o caso.

Em resumo, enquanto latino-americanos afrodescendentes encontram alguma utilidade ao recorrer aos marcos do direito internacional, as dificuldades para cumprimento das recomendações, prazos longos e o limitado acesso às ferramentas do direito internacional reforçam a necessidade de reforma dos sistemas jurídicos domésticos, para que se promova a igualdade racial. De fato, a Assembleia Geral da Organização dos Estados Americanos tem apontado que há dificuldades em lidar com a discriminação racial com base na categoria mais ampla de direitos humanos. Como resultado, a OEA, em 2000, iniciou um projeto para o desenvolvimento de uma Convenção Interamericana contra o Racismo e todas as Formas de Discriminação e Intolerância. (ORGANIZATION OF AMERICAN STATES INTERNATIONAL LAW DEPARTMENT, 2009) Desde então, um projeto de convenção tem sido elaborado e sessões especiais estão sendo conduzidas com o propósito de promover a adoção pelos Estados membros da OEA. Se amplamente adotada, a convenção poderia apoiar pesquisas para promover a consciência da discriminação racial na região, além de monitorar padrões de disparidade racial nos Estados. Através da identificação de pessoas de ascendência africana nas Américas como sujeitos de direitos, a convenção ajudaria a importante luta de fazer com que os Estados compreendam e lidem com as desigualdades raciais.

Contudo, existe resistência para a adoção da Convenção Interamericana contra o Racismo e Todas as Formas de Discriminação e Intolerância. (KAMIENSKA-HODGE, K.; LAJZER, J., 2009) Alguns Estados-membros têm se oposto à criação de uma convenção exclusiva sobre racismo e, em contrapartida, propõem que a convenção seja mais ampla e abranja outras formas de preconceito e marginalização, como a idade, origem nacional e muitas outras. A visão de que a discriminação racial não é a perspectiva mais importante na abordagem de problemas sociais na América Latina justifica a resistência à convenção sobre racismo e acaba fazendo com que a mesma não avance. Essa perspectiva destoa bastante do marco legal internacional das últimas décadas, o qual tem optado pelo uso de convenções dedicadas a temas únicos. Por exemplo, há uma convenção focada em gênero, Convenção Interamericana para a Prevenção, 
Punição e Erradicação da Violência contra as Mulheres, e há uma convenção voltada às pessoas com deficiência, Convenção Interamericana para a Eliminação de Todas as Formas de Discriminação Racial contra Pessoas com Deficiência. Também houve uma enorme mudança em relação ao modo como foi concebida, em 2000, a Convenção Interamericana contra o Racismo e Todas as Formas de Discriminação e Intolerância, como um mecanismo para tornar o foco antirracista da Convenção Internacional para a Eliminação de Todas as Formas de Discriminação Racial (Icerd) mais relevante para as necessidades das Américas, uma vez que o foco inicial da Icerd, 40 anos atrás, foi voltado para questões de apartheid e colonialismo. Ao longo do tempo, o aporte dos vários Estados-nações buscou diluir a atenção dada predominantemente ao racismo, de modo a refletir a concepção da América Latina como racialmente inocente. Baseado na noção de que os Estados latino-americanos são inocentes de terem cometido atos racistas, por não ter havido uma segregação estatal no estilo Jim Crow na região, delegações de Estados-nações latino-americanos consideram o racismo uma aberração, em vez de considerá-lo uma parte sistêmica de cada cultura nacional. A explicação dada neste livro sobre o papel do direito costumeiro de regulação racial na América Latina contradiz radicalmente essa perspectiva e talvez pudesse ser de utilidade nos esforços para vencer a resistência a uma convenção exclusiva para tratar do racismo no sistema interamericano. Invocar o histórico do direito costumeiro de regulação racial pode conferir aos atores de movimentos de justiça social o poder retórico necessário para desacreditar a noção da inocência racial do Estado, que impede a consideração de medidas efetivas e corretamente orientadas para lidar com o racismo em uma convenção específica sobre raça.

A América Latina aos poucos vem tirando a máscara da suposta democracia racial e está começando a estabelecer mecanismos para reconhecer os prejuízos da discriminação racial. Mas para uma população que, por tanto tempo, tem se considerado livre da crueldade da discriminação ao estilo da estadunidense, os latino-americanos afrodescendentes ainda são desproporcionalmente pobres, mais atingidos pelo desempregado e menos beneficiados pela educação formal se comparados ao restante da população. $\mathrm{O}$ desenvolvimento de estruturas antidiscriminação na América Latina certamente será uma ferramenta útil para auxiliar os afrodescendentes a lutar por igualdade racial. Contudo, ainda há muito a ser feito. Movimentos de afrodescendentes estão conscientes de que proteções jurídicas mais amplas ainda são necessárias contra a discriminação 
racial. Como resultado, além de fazer lobby pela aplicação mais efetiva de direitos civis, os movimentos de justiça social também lutam pela implementação de políticas obrigatórias de ação afirmativa, conforme a discussão feita no próximo capítulo. 